\title{
Problems and Countermeasures of Family Education in the New Media Era
}

\author{
Songtao Li \\ School of Education and Sports, Bohai University, Jinzhou, 121013, China \\ lisongtao2008@yeah.net
}

Keywords: new media era; family education; parents; children

\begin{abstract}
Family is the first classroom for every child and parents are the first teachers of the children. Family education is crucial to the growth of each child. The new media era has brought both opportunities and challenges to the development of family education. Under the impact of the new media era, there still exist some problems in terms of family education, such as the backwardness of educational concept, the absence of social support system and the low quality of parents' education. With the help of Rousseau education theory, the paper put forward the following strategies: the innovation of the education concept and practice, the improvement of the social support system, with the purpose of creating a more perfect family education environment.
\end{abstract}

\section{Introduction}

Family education which is the first education in life is the foundation and starting point of all education. It not only plays an important role in the development of personal emotion, will, personality, life, learning and moral character, but also affects family harmony, social stability and education promotion [1]. "2014 China's urban and rural family education white paper" shows that the parents do not know the educational methods of the $37.82 \%$, no time to educate children, accounting for $26.19 \%$. More than half of parents said that when the child has problems, hoping to get professional help. There are $81.4 \%$ parents think that family education has a lot of knowledge needs to learn and train. This means that children' education has become the biggest knowledge of defects for Chinese parents [2]. But at present, the society can provide parents with the system of family education is not enough to meet the needs of parents. The advent of the new media era brings a new pattern for family education, which provides an opportunity for the development of family education. However, what are the problems of family education in the era of new media? What is the role of new media in family education? How to integrate the positive impact of new media into family education? To make it more in line with the development of the times, to create a healthy environment for children' education. These are the problems to be solved in this paper.

\section{Family Education and New Media Era}

Family is the first class of children, parents are children' first teachers, family education is very important for children' growth. The new media era has brought a new pattern for family education, the new media is good or bad in family education? How the traditional family education should be integrated with the new media? In the era of new media, how to develop family education, there will be more in line with the development of the times and a better environment for education, and a healthy growth of children.

(1) Family education and its characteristics [3]. Family education refers to the education and upbringing of young people by the older people in the process of human being's socialization. Meanwhile, this kind of activity has a subtle influence on family members. Family education is centered on parent-child relationship, which has the characteristics of spontaneity, randomness and dispersion. First of all, spontaneous refers to the parents will naturally take on the function of family education when the child was born, in the speech to the ideological style of thinking, both play a subtle role in infiltration and education for children. Secondly, randomness means that the family 
education is not like school education as a classroom, teaching materials, a system. Family education is not limited by time, place, place and condition. Through the practice of life or participating in activities with their children. The use of all available opportunities to educate their children in flexible methods which children are easy to accept. Finally, scattered refers that words and deeds in the state of nature expressed are likely to become the education of "points" on parents, the "point" consists of "morality, intelligence and physique" and so on. Because of family environment and conditions, the influence of parents concept, these " point" are not in Systematization. All-round development of children also need to rely on social education and school education.

(2) The meaning and characteristics of the new media era [4]. New media era is relative to the traditional media, such as newspapers, radio, television and other traditional media, with the help of the Internet, satellite, wireless communication network and other mobile terminals, such as mobile phones, computers, digital TV terminals, to provide users with information and entertainment services of other forms of communication and media. This paper mainly analyzes the new media era from the perspective of family education. The features are below: First, mass information. Traditional media limited amount of information, however, the new media era, the Internet, mobile phones and other terminals can provide quantitative information for the family education. Second, fragmentation of knowledge. The era of new media to provide knowledge and information more timely, with geometric growth. Therefore, the knowledge is also more fragmented. Third, virtualization. The new media era provides more virtual information and the environment. Fourth, strong interaction. Mobile phone Shuabing can quickly through dialogue and exchanges, interaction between family members is more powerful. Fifth, the integration of video, sound and word. In the new media era, it can provide the integration of video, sound, text and other aspects, making more interesting of family education. Sixth, openness. The era of new media attention to the open space for children to learn, the child can not only learn at school, can also learn at home. The network provides a platform for children to learn.

(3) The era of new media brings opportunities for family education [5]. From the point of view of educational content, educational resources are enriched. The new media with its openness, immediacy, global characteristics, making the communication between parents and children more direct and convenient, children can express their views through the new media, the expression of ideas. The new media has the characteristics of interactivity, so that children can be very convenient to actively look for the information required, the new media is an important platform for children to learn actively. From the view of education form, it expands the space of education. New media vivid variety of information dissemination, meets the child's desire to communicate with the psychological characteristics of equality, family education is more broad. The new media breaks through the limitations of time and space, with its flexible, fast, interactive, to meet the needs of children' learning, life, emotional needs. At the same time, in the subtle influence on children' outlook on life and values education. From the point of view of education effect, it strengthens the pertinence of family education. The "two-way", interactive, open education, attracts children' active participation, enhances the effectiveness of family education. The new media network virtualization platform in the exchange will be easier for parents and children on an equal footing, eliminate the child's psychological alert and estrangement, closer to the parents and child's psychological distance, is conducive to the parents for the first time to grasp the idea of dynamic child targeted education.

\section{Problems of Family Education in the New Media Era}

New media era brings opportunities for family education. However, in the era of new media, there are still many problems in family education. In addition to their own problems, there are still problems such as backward family education concept, outdated methods, a single way, lack of effective social support system and so on.

(1) The backwardness of family education. For thousands of years, the traditional concept of family education in China is to parents as the standard, the parents have absolute rights and dignity, children can only obey parents to filial piety, otherwise it will be denounced as unfilial. When 
parents call the shots, the attitude of parents to their elders to teach their children, not equality status and discourse power between old and young [6]. In the new media era, the child through mobile phones, computers, i-pad and other ways to obtain massive information resources and a wide range of interpersonal communication opportunities can not imagine in the past. There are many channels to acquire knowledge and information in the era of new media, and the knowledge authority of elders has been challenged by the new media. The concept of "old standard" as the center of the traditional family education is gradually being subverted by the growing young people under the background of the new media era. It has brought more new ideas to the parents, but the development of new media has also put forward higher requirements for the quality of their parents. At this point, if you can not clearly understand the role of parents in the new media era, what should be done, what to do, how to teach children, etc., then home education is doomed to be unsuccessful. Therefore, it is very important for us to re-examine the role of parents, recognize the situation of the new media era, and grasp the children' psychology and ideology, which is of great significance to the renewal of educational ideas and the improvement of education.

(2) Absence of social support system. The social support system of family education refers to all sectors of society, especially the relevant government departments, including all levels of administrative departments of education, schools and research institutions for the study of family education, guidance, training, service and management[7]. The importance of family education is becoming more and more prominent, but the social support system is absent. First, in the new media era, the quality of home reading books are worried. The new media and books of type and number are countless on home education, books related to the theory of family education, family education, quality education, etc., covering the scope of books at all times and in ancient times...... It can be said that the new media market of home education. However, the relevant publishing companies and the media for home reading books in the dissemination of scientific knowledge, research issues of professional, educational countermeasures and other aspects of strict control, the quality of reading books are varied. Second, home-school cooperation mechanism is not perfect. In order to strengthen the home-school cooperation in our country, the administrative department of education and family education has the responsibility of guiding women' organizations to take a series of initiatives in recent years, such as clear parents committee system, the country according to the actual situation, the establishment of home school communication network platform, the mobilization of universities and educational research institutions to carry out family education project, theory guidance to schools and parents. Because of the education administrative departments at all levels and the division of women' organizations "in guiding family education dislocation and schools and parents connected not properly, function of home-school cooperation mechanism of the existing play faces many limitations.

(3) Parents' educational quality lags behind. First, the sensitivity of new things is not enough. In the new media era, as long as there is support for mobile phones, computers and other mobile devices and the Internet, the child can communicate with each other at any time and family or classmates. Correspondingly, the parents' education form and education method should be changed accordingly. Secondly, the knowledge reserve is not enough. The rapid development of modern science and technology, knowledge and skills to update more than ever before, if the parents can not update their knowledge, learn new skills, it is difficult to change the face of the new media era of family education mode. Again, burnout and avoidance psychology. In the face of heavy work and family burden and the pressure of competition, a lot of parents for children education and inadequate, for some new, do not understand things, often negative conflict avoidance behavior and psychology. Therefore, in the face of family education mode in the new media age, parents have a psychological crisis. Finally, the action can not "set an example". Many parents in the material to meet the needs of children to learn, but ignore the importance of setting a good example to set an example for the children, also paid little attention to optimistic family atmosphere can make children form a positive mental state, also do not use their wisdom to help children avoid temptations from new media, electronic games, mobile phone at the Internet era and adverse effects. In this environment, the child is very uncomfortable to a good family education [8]. 


\section{The Countermeasures of Family Education in the New Media Era}

Through the above analysis, the existence of family education problems in the new media era, combined with the related theory and literature, explore some of the family education in China to solve the problem of the new media background of the practical and effective countermeasures.

(1) To promote the theory and practice of family education. First of all, according to the child's personality characteristics, to determine the appropriate content of media education. Rousseau said, "every heart has its own form, must go through this form of education which, in order to achieve results", "to respect the children, do not rush to judge good or bad for him, to really understand children, to teach students in accordance with their aptitude" [9]. The parents should be find the child's personality, and help children to identify appropriate content of media education, make their individuality development, then children grow, become the people they should be, rather than the success of parents' thinking, this is the value of family education, naturally resolve the utilitarian orientation of family education. Secondly, to construct a harmonious family education environment. The important role of environment to personal growth is self-evident. Good family education environment is the foundation of education. Among the new media age, children should learn, and parents too. Learning together with children is also need, or even to learn from the children to close with the child's psychological distance, concerned about the child's emotional world, effective parent-child communication. Finally, help children to establish a correct view of the network. On the one hand, parents create a healthy Internet environment for children. Families buy computer and networking, to avoid the child to go to Internet cafes; on the other hand, to develop good surfing habits, reasonable arrangements for academic and online entertainment time. Computers are put as far as possible in the living room and other open areas, to play a supervisory role.

(2) To improve the social support system of family education [10]. Relevant government departments and educational institutions should play an active role in establishing and improving the social support system of family education. First, the relevant media management and supervision departments should strictly supervise the quality of home reading books. Encouraging the family education experts and sociologists according to the characteristics and laws of child growth and development, prepared with children of different age family education books, and hired at all levels of family education guidance committee of experts, in accordance with the national family education outline standards for family education reading checks, and the implementation of strict screening, evaluation and promotion of reading tutoring mechanism. For the existing outstanding family education popular science books, in respect of copyright and Copyright under the premise of online parents can be achieved through the school, to realize excellent social sharing of family education resources. Second, improve the home school cooperation mechanism. In view of the fact that the parent school is attached to the kindergarten and primary and secondary schools, the teachers mainly come from universities and research institutions, it is a wise choice to put the parent schools under the unified management of the education system. The education department should take the responsibility of the parents' school curriculum construction and quality control to ensure the normal operation of the parent school. In accordance with the unified responsibilities and powers of the unified principle, kindergarten, primary and Secondary School Parents Committee, Working Committee on women and children should be classified at all levels of leadership and management, safeguard the rights and interests of minors based on the position, better play the role of a bridge between the exercise of rights for education appraisal rights, participation and supervision, make it really become the construction of an important platform for power up the exchange of experience, family education, school education and parents school evaluation.

(3) Improve parents' education quality. First, open your mind to new things. The parents brought to meet the challenge of new media need to open mind to accept the new media age education form, to fully understand the new media education value, and with a positive attitude to accept and into their own knowledge and ability education. Secondly, establish the concept of lifelong learning. In the face of changing educational idea brought about by the new media era, diversified education forms, parents must set a new media era of the thought of learning, to achieve lifelong learning, which in terms of knowledge and skills to learn the essence of education in the new media era. 
Third, strengthen exchanges and communication with children. It is undeniable that the era of new media has greatly broadened the channels and ways of children' interpersonal communication, but the communication between parents and children is no substitute for any other relationship. Parents in the emotional aspects, the need to understand the child's psychological needs in a timely manner, WeChat, text messages and other ways to communicate with the child equality and dialogue, into the child's inner world. Finally, action, set an example. On the one hand, the parents need to update knowledge and skills, and constantly enrich and improve themselves. On the other hand, they should try to avoid the bow family phenomenon. Read more, learn more, create a positive family atmosphere and family environment for the children, and give full play to the advantages of the new media era, to help children avoid the temptation and impact of mobile phones, video games and the Internet and so on.

\section{Conclusion}

The rapid development of new media has a profound impact on people's way of life, but also changes in school education, parent-child relationships and children' growth environment. New media is a "double-edged sword", on the one hand, the new media technology to create a new mode of family education is diverse and rich, the development of home school interaction, e-Schoolbag and digital education platform, to create a wider space for the development of children learning potential, and re-interpretation of family relationship. On the other hand, the use of tablet PCs, smart phones make children appear obsessed with online games. Bad information online on the child's growing influence is apparently. Therefore, in the era of new media, it is necessary to change the concept of family education and educational methods, pay attention to cultivate children' creative thinking, cooperation and sharing ability and high emotional intelligence has become the key to the core competitiveness of students; Secondly, the relevant government departments and the media supervision departments should play a role in establishing and improving the social support system of family education, and finally, to improve the quality of their parents, and actively respond to the new media era. As parents, can not refuse the new media environment, to put the child in the appropriate development environment. Efforts to narrow the gap between children and the community, especially with the frontier science and technology gap, so that children can grow up with society. Family education should make full use of the new media era brought the opportunity, actively facing the new media era "challenge", let the family education and new media integration, to create a better environment for family education.

\section{Acknowledgement}

This work is supported by Liaoning educational science project for the 13th Five Year Plan (2016) (JG16EB022): Research on the Construction of Social Support System of Family Education.

\section{References}

[1] S. Luo, "The System of Guidance and Service for Family Education in Taiwan and its Implication." Journal of Capital Normal University (Social Sciences Edition), vol. 43, no. 3, pp. 128-135, 2015.

[2] J. Ke, "Family Education has Become the Weakest Point of Chinese Parents," China Education Daily, 2014-12-29 (3).

[3] H. Liu, "Action Research on Family Education in the New Media Era." Modern Education, vol. 2, no. 5, pp. 53-55, 2014.

[4] D. Liu, Z. H. Wang, "Teachers' Psychological Crisis and Its Solution in the New Media Era," Teaching and Management, vol. 32, no. 5, pp. 65-67, 2015. 
[5] S. Y. Wang, J. S. Zhang, "Collaborative Innovation of College Students' Ideological and Political Education in the New Media Era," Continuing Education, vol. 32, no. 1, pp. 83-84, 2015.

[6] T. B. Ma, "Lun Xun's Thinking about Family Education," Education Exploration, vol. 36, no. 8, pp. 6-8, 2016.

[7] F. Luo, "The Modernization of Family Education and Its Practice from the Perspective of Chinese Dream," Journal of Socialist Theory Guide, vol. 37, no. 2, pp. 98-105, 2015.

[8] F. Dai, "Problems and Countermeasures of Family Education in China: an Analysis Based on Rousseau's Theory of Natural Education," Education Exploration, vol. 37, no. 4, pp. 36-38, 2015.

[9] H. Zhang, "Curriculum and Teaching Methodology," Shanghai: Shanghai Educational Publishing House, 2012.

[10] H. zhang, "The Idea and Strategy of Constructing the Social Support System of Family Education with Chinese Characteristics," China Youth Study, vol. 37, no. 10, pp. 109-113, 2015. 